\title{
Survival, Growth, and Productivity of Rhizophora Racemosa Transplanted in Natural Ecosystems: Implications for Mangrove Restoration
}

\author{
Laurenda Corine Bitossessi Sinsin \\ Universite d'Abomey-Calavi Faculte des Sciences Agronomiques \\ Kolawolé Valère Salako ( $\square$ salakovalere@gmail.com ) \\ Universite d'Abomey-Calavi Faculte des Sciences Agronomiques https://orcid.org/0000-0002-7817-3687 \\ Roméo Jesukpégo Tohoun \\ Universite d'Abomey-Calavi Faculte des Sciences Agronomiques \\ Romain Glèlè Kakaï \\ Universite d'Abomey-Calavi Faculte des Sciences Agronomiques
}

\section{Research Article}

Keywords: red mangrove, restoration, salinity, nursery, growth, biomass

Posted Date: February 9th, 2022

DOI: https://doi.org/10.21203/rs.3.rs-1312951/v1

License: (a) (1) This work is licensed under a Creative Commons Attribution 4.0 International License. Read Full License 


\section{Abstract}

Mangroves are coastal wetland ecosystems of tropical and subtropical regions. Their development and trajectories are mainly driven by water and substrate salinities. Therefore, understanding how main mangrove species respond to salinity gradient when transplanted in natural environment is essential for their restoration. This study assessed the survival, growth, and productivity of Rhizophora racemosa seedlings in response to gradient of salinity. Seedlings were grown in nursery under low (3-5 psu) and medium (15-17 psu) water salinities for thirty days and transplanted to three mangrove sites with various salinities $(4.6,11.41$, and 18.27 psu). Seedling survival and growth were monitored monthly for 6 months. At the end of month 6 , total biomass was harvested and partitioned. Results showed that growth, survival, and productivity of $R$. racemosa were mainly influenced not by the salinity under which the propagules were raised in nursery but rather by site. Survival was higher (88.33\%) at the site with the highest salinity. Total plant biomass was similar across sites, but root biomass and root weight ratio were higher on sites with higher salinity. Biomass was disproportionately higher in stems $(45-54 \%)$ than in roots $(28-37 \%)$, and leaves $(15-18 \%)$. We suggest that restoration is done in appropriate period, ideally one month before the start of rainy season not only to allow seedlings to well establish their rooting system in the substrate before rains start but also to favour seedling growth, because of substrate salinity dilution by fresh water from rains and flows from uplands.

\section{Introduction}

Mangroves are peculiar wetland ecosystems, providing multiple ecosystem services. They are however increasingly being degraded, and several current actions are focused on their restoration. Restoration and sustainable management of mangroves require an understanding of the functioning of the ecosystem components, particularly dominant species. Water and soil substrates salinities are key abiotic factors influencing functioning of mangroves. The establishment and equilibrium of mangroves require optimal salinity ranges in both water and soil substrates, which differ among species (Khan and Aziz 2001; Stern and Voigt 1959). While, some mangrove species are facultative halophyte, others are obligate halophyte (Wang et al. 2011). Consequently, optimum salinity range is large (Ball and Pidsley 1995) and a uniform framework cannot be applied to all species, rather understanding of speciesspecific response to salinity is needed to design tailored restoration guidelines. For instance, occurrence of species from the genus Avicennia fits within salinity of 12-14 psu while Ceriops decandra (Griffith) Ding Hou requires salinity up to 27-28 psu and Sonneratia apetala Buch. Ham adapts to a wide range of salinity (Dasgupta et al. 2017).

West-Africa shares $10.3 \%$ of global mangroves and $55.93 \%$ of mangroves in Africa. However, mangroves of the region have been comparatively less studied. The West African mangrove ecosystems are less species-diverse, made of only eight mangrove plant species (Saenger 1995) of which Rhizophora racemosa (G.) Meyer is the most widespread. Restoration of degraded mangroves are mainly based on $R$. racemosa. Usually, young plants are produced in nursery, and then transplanted in natural stands. Though $R$. racemosa is well documented (Duke and Allen 2006), its physiological response to environmental stresses is still not clear, especially for ecotypes from West Africa. Such information is crucial for planning, monitoring, and evaluation of mangrove restoration initiatives. For e.g., careful choice of matching nursery practices (mainly salinity) and restoration sites (salinity ranges) would improve success of restoration efforts.

The main objective of this study was to assess the survival, growth, and productivity responses of $R$. racemosa to gradient of saline conditions. Specifically, the study compared survival, growth in height, biomass allocation (aboveground versus belowground) and partitioning among roots, stems, and leaves of $R$. racemosa, at three mangrove sites experiencing different natural salinity conditions. Assuming that nursery conditions, particularly watering salinity under which seedlings are grown before being transplanted in natural environments may affect their performance, the study tested the effect of salinity (of water used to raise seedlings in nursery) on juveniles' survival, growth, and productivity. The study examined the hypothesis that survival, growth, and productivity of $R$. racemosa negatively correlate with salinity based on previous reports that Rhizophora spp are less salt tolerant (Duke and Allen 2006). Furthermore, according to the optimal partitioning theory, plants allocate more biomass to the organ capturing the most limiting resource (Kobe et al. 2010), suggesting that relationship between above and belowground biomass may change in stress conditions (e.g., high salinity). Yet, regarding biomass partitioning between above- and below- ground, Enquist and Niklas (2002) proposed that juveniles have an isometric relationship between above and belowground biomass (i.e., slope $=1$ ). Assuming that the difference in salinity conditions in nursery and differences in salinity conditions among transplantation are potential sources of stress to the transplanted seedlings, we also predicted a shift from the isometric relationship between above and belowground biomass at sites with higher salinities, and for individuals raised under higher water salinities.

Page $2 / 17$ 


\section{Material And Methods \\ Study sites}

The study was conducted in Benin, at three sites, namely Azizakouè, Djègbamé, and Lanhou along lagoon of Grand Popo (Fig. 1). The climate is equatorial, with an average rainfall of $1360 \mathrm{~mm} /$ year across the three sites. However, there are differences in physicochemical features, especially with regards to salinity (Table 1). The sites are all islands located at latitude N: 6.31 and longitude E: 1.97 (Azizakouè), latitude N: 6.32 and longitude E: 1.97 (Djègbamé), and latitude N: 6.31 and longitude E: 1.92 (Lanhou). The experiment sites were all in natural mangrove stands characterized by clay-muddy soil covered by the lagoon water in period of high tides (July to December).

Table 1

Physico-chemical characteristics of experiment sites: mean \pm standard error

\begin{tabular}{|llll|}
\hline Parameters & Azizakouè & Djègbamey & Lanhou \\
\hline Salinity $(\mathrm{psu})$ & $18.16 \pm 0.46$ & $11.60 \pm 1.14$ & $4.60 \pm 1.78$ \\
\hline $\mathrm{Ph}$ & $6.90 \pm 0.21$ & $6.90 \pm 0.14$ & $7.00 \pm 0.78$ \\
\hline Temperature $\left({ }^{\circ} \mathrm{C}\right)$ & $31.30 \pm 0.87$ & $31.50 \pm 1.15$ & $31.60 \pm 0.26$ \\
\hline Conductivity $(\mathrm{ms} / \mathrm{cm})$ & $29.20 \pm 0.62$ & $29.60 \pm 1.78$ & $29.20 \pm 0.60$ \\
\hline Dissolved oxygen $(\%)$ & $2.40 \pm 0.26$ & $2.30 \pm 0.26$ & $2.50 \pm 0.15$ \\
\hline Oxygen rate $(\%)$ & $35.40 \pm 4.28$ & $35.20 \pm 3.86$ & $35.90 \pm 1.47$ \\
\hline Atmospheric pressure $(\mathrm{PSI})$ & $14.90 \pm 0.07$ & $14.90 \pm 0.02$ & $14.90 \pm 0.01$ \\
\hline Rate of dissolved solids $(\mathrm{ppt})$ & $14.77 \pm 0.30$ & $14.50 \pm 0.23$ & $14.20 \pm 0.14$ \\
\hline Orthophosphate & $66.51 \pm 14.27$ & $66.25 \pm 7.96$ & $67.00 \pm 4.40$ \\
\hline
\end{tabular}

\section{Experiment setting}

One-month old seedlings of $R$. racemosa were first produced in nursery (nylon bag filled with substrate) at Kpèko (latitude N: 6.32 and longitude E: 1.91) but watered with either low (3-5 psu) or moderate (15-17 psu) water salinity. At this stage, seedlings raised under low salinity were relatively taller $(6.07 \pm 0.38)$ compared to seedlings raised under moderate salinity $(5.69 \pm 0.38)$. Similarly, the number of leaves was significantly higher for seedlings raised under low salinity $(2.42 \pm 0.08)$ than for seedlings raised under moderate salinity $(1.82 \pm 0.07)$ (Sinsin et al. 2021).

For the experiment of transplantation into natural ecosystems, 45 seedlings of $R$. racemosa were considered for each treatment (level of watering salinity) on each site; which made 45 seedlings $\times 2$ levels of watering salinity $\times 3$ sites $=270$ seedlings. At each site, the 90 seedlings were arranged in a randomized complete block design with 3 replicates. The experimental unit was a plot consisting of 3 rows, each row receiving five seedlings planted at $1 \mathrm{~m}$ (between two seedlings) $\times 1 \mathrm{~m}$ (between two rows) spacing, with a sowing depth of $15 \mathrm{~cm}$. Nylon bags were torn and removed before transplantation. Seedlings did not receive any post sowing maintenance; they were left to face constraints from their new environment as usually practiced in mangrove restoration projects.

\section{Data collection}

\section{Survival and growth}

After experiment was settled, each month, for 6 months (from June 2019 to November 2019), seedlings' survival (yes or no) was monitored. Data on growth parameters namely total height and number of leaves were also collected monthly, on each seedling. Productivity/Biomass estimation

At the end of the experiment (6th month), five seedlings were randomly selected and harvested from each block (3 blocks per site) per level of "salinity of water in nursery" (hereafter "salinity"); making a total of 30 seedlings per site. Hypocotyl length, total stem 
length (= epicotyl + hypocotyl), and taproot length (from the base of the stem until the taproot had approximately $5 \mathrm{~mm}$ diameter (see Cuni Sanchez et al. 2011); the remaining roots were considered fine roots) were measured with a graduated ruler. Stem and taproot diameters were measured at the collar. Thereafter, the first three leaves from the top of each sampled plant were collected, packed separately, and measured for their total length and width. To measure the specific leaf area, the widest possible section was extracted (using a blade) for each of the first three leaves; length and width of each section was measured, the sections were ovendried at $80^{\circ} \mathrm{C}$ up to constant weight (at the laboratory), and SLA was estimated following Gbeffe et al. (2017). For the estimation of biomass component, each selected seedling was up-rooted and separated into different parts including epicotyl (from the top to the node from which starts the hypocotyl), hypocotyl (from the node from which the epicotyl ends up to the stem base), taproot, fine roots, other leaves, and branches. Sectioned samples from each part were weighted in the field (using an electronic scale) and later dried in an oven at $80 \circ \mathrm{C}$ up to constant weights.

\section{Data processing and statistical analysis}

Survival and growth

Survival at time t, $S(t)$ of transplanted individuals in relationship to site and salinity, was estimated using the non-parametric Kaplan-Mayer method (Onofri et al. 2010). The estimator of the survival $S(t)$, that is the probability that life is longer than $t$, is given for a time $t_{i}$ by:

$$
\hat{\mathrm{S}}(\mathrm{t})=\prod_{\mathrm{i}: \mathrm{t}_{\mathrm{i}} \leq \mathrm{t}}\left(1-\frac{d_{\mathrm{i}}}{\mathrm{n}_{\mathrm{i}}}\right)
$$

In this equation $d_{i}$ is the number of seedlings that did not survive in the interval of time $\mathrm{i}, n_{i}$ is the number of seedlings known to have survived up to time $t_{j}$ and $\prod$ stands for products. The estimation of the survival function was done in the package "survival" (Therneau and Grambsch 2000).

Linear mixed model (LMM) on longitudinal data with a normal distribution for errors was used to assess variation in time of plant total height in relationships to the fixed effects of "sites" and "salinity" and the random effect of "block". The models were run with the packages "nlme" (Pinheiro et al. 2018). Similarly, generalized linear mixed model (GLMM) on longitudinal data was applied on the number of leaves using the Poisson error distribution. GLMM was run using package "MASS" (Venables and Repley 2002). Anova was used to test the overall significance of fixed effects. The random effect of block was assessed through the Intra Class correlation (ICC). The block random effect in the data was assessed by fitting unconditional means models (Singer and Willett 2003).

\section{Biomass productivity}

Productivity indices such as Total Plant Biomass (TPB), Aerial Biomass (AB), Root Biomass (RB), Taproot Ratio (TPR), Shoot Root Ratio (SRR), Leaf Weight Ratio (LWR), Stem Weight Ratio (SWR), Root Weight Ratio (RWR), Top Weight Ratio (TWR), Leave Morphology Index (LMI), Specific Leaf Area (SLA), Leaf Water Content (LWC), Stem Water Content (SWC), and Root Water Content (RWC) were calculated per seedling. Table 2 summarizes each index, its formula, and its importance to the description or estimation of growth and productivity. Linear mixed effect model (LMM) was also performed to assess the influence of salinity and sites on each index. In these models, salinity and sites were considered as fixed whereas block was random. The models were run with the Imer function of the package "ImerTest" (Kuznetsova et al. 2019). To test the prediction of a shift from the isometric relationship between above and below-ground biomass at sites with higher salinities and for individuals raised with higher salinities (nonparallelism of slopes), we fitted a linear model, particularly and analysis of covariance (ANCOVA) with above-ground biomass (leaves plus stems) as a function of below-ground biomass (roots), including interactions of below-ground with salinity on one hand and with site on the other hand. 
Table 2

Growth/productivity indices: formula, description, and relevance

\begin{tabular}{|c|c|c|c|c|c|c|}
\hline $\begin{array}{l}\text { Growth } \\
\text { parameters }\end{array}$ & Symbol & Unit & Formula for calculation & $\begin{array}{l}\text { Description of } \\
\text { formula }\end{array}$ & $\begin{array}{l}\text { Relevance of } \\
\text { the parameter/ } \\
\text { index for this } \\
\text { study }\end{array}$ & References \\
\hline $\begin{array}{l}\text { Plant total } \\
\text { height }\end{array}$ & $\mathrm{Ht}$ & $\mathrm{Cm}$ & $\sum_{i=1}^{n} H t_{i} / n$ & $\begin{array}{l}H t_{i} \text { is the } \\
\text { length of the } \\
\text { sapling at the } \\
\text { day of } \\
\text { biomass } \\
\text { collection (six } \\
\text { months); It } \\
\text { was } \\
\text { measured } \\
\text { from the base } \\
\text { of the stem } \\
\text { until the apex } \\
\text { of the } \\
\text { sapling's } \\
\text { terminal bud. } \\
n \text { is the total } \\
\text { number of } \\
\text { seedlings } \\
\text { considered }\end{array}$ & $\begin{array}{l}\text { Structural } \\
\text { indicator of } \\
\text { growth }\end{array}$ & \\
\hline $\begin{array}{l}\text { Hypocotyl } \\
\text { height }\end{array}$ & $\mathrm{Hh}$ & $\mathrm{Cm}$ & $\sum_{i=1}^{n} H h_{i} / n$ & $\begin{array}{l}H h_{i} \text { is the } \\
\text { length of the } \\
\text { hypocotyl at } \\
\text { the day of } \\
\text { biomass } \\
\text { collection (six } \\
\text { months); It } \\
\text { was } \\
\text { measured } \\
\text { from the base } \\
\text { of the stem } \\
\text { until the base } \\
\text { of the } \\
\text { epicotyl. } n \text { is } \\
\text { the total } \\
\text { number of } \\
\text { seedlings } \\
\text { considered }\end{array}$ & $\begin{array}{l}\text { Structural } \\
\text { indicator of } \\
\text { growth }\end{array}$ & \\
\hline $\begin{array}{l}\text { Basal } \\
\text { circumference }\end{array}$ & $\mathrm{Cb}$ & $\mathrm{Cm}$ & $\sum_{i=1}^{n} C b_{i} / n$ & $\begin{array}{l}\mathrm{Cb}_{i} \text { is the } \\
\text { circumference } \\
\text { of sapling i at } \\
\text { the day of } \\
\text { biomass } \\
\text { collection (6 } \\
\text { months); It } \\
\text { was measure } \\
\text { with tailor } \\
\text { meter. } n \text { is the } \\
\text { total number } \\
\text { of seedlings } \\
\text { considered }\end{array}$ & $\begin{array}{l}\text { Structural } \\
\text { indicator of } \\
\text { growth }\end{array}$ & \\
\hline $\begin{array}{l}\text { Total Plant } \\
\text { Biomass }\end{array}$ & TPB & G & $\sum A B+R B$ & $\begin{array}{l}\text { Sum of the } \\
\text { dry weight of } \\
\text { all parts of } \\
\text { the sapling }\end{array}$ & $\begin{array}{l}\text { It informs on } \\
\text { the species } \\
\text { productivity at } \\
\text { juvenile stage } \\
\text { as a response } \\
\text { to salt } \\
\text { gradient and } \\
\text { sites }\end{array}$ & $\begin{array}{l}\text { Cuni } \\
\text { Sanchez et } \\
\text { al. (2011) }\end{array}$ \\
\hline
\end{tabular}




\begin{tabular}{|c|c|c|c|c|c|c|}
\hline $\begin{array}{l}\text { Growth } \\
\text { parameters }\end{array}$ & Symbol & Unit & Formula for calculation & $\begin{array}{l}\text { Description of } \\
\text { formula }\end{array}$ & $\begin{array}{l}\text { Relevance of } \\
\text { the parameter/ } \\
\text { index for this } \\
\text { study }\end{array}$ & References \\
\hline $\begin{array}{l}\text { Aerial } \\
\text { Biomass }\end{array}$ & $A B$ & G & $\sum D W_{\text {leaves }}+D W_{\text {branches }}+D W_{\text {stem }}$ & $\begin{array}{l}\text { Sum of dry } \\
\text { weights (DW) } \\
\text { of all parts of } \\
\text { the sapling } \\
\text { that are } \\
\text { aboveground }\end{array}$ & $\begin{array}{l}\text { Indicator of } \\
\text { growth and } \\
\text { productivity, it } \\
\text { informs on the } \\
\text { species } \\
\text { investment in } \\
\text { aboveground } \\
\text { parts at } \\
\text { juvenile stage } \\
\text { for different } \\
\text { salinity and } \\
\text { sites }\end{array}$ & $\begin{array}{l}\text { Cuni } \\
\text { Sanchez et } \\
\text { al. (2011) }\end{array}$ \\
\hline Root Biomass & $\mathrm{RB}$ & G & $\sum D W_{\text {taproot }}+D W_{\text {otherroots }}$ & $\begin{array}{l}\text { Sum of dry } \\
\text { weights (DW) } \\
\text { of all parts of } \\
\text { the sapling } \\
\text { that are } \\
\text { belowground }\end{array}$ & $\begin{array}{l}\text { Indicator of } \\
\text { growth and } \\
\text { productivity, it } \\
\text { informs on the } \\
\text { species } \\
\text { investment in } \\
\text { belowground } \\
\text { parts at } \\
\text { juvenile stage } \\
\text { for different } \\
\text { salinity and } \\
\text { sites }\end{array}$ & $\begin{array}{l}\text { Cuni } \\
\text { Sanchez et } \\
\text { al. (2011) }\end{array}$ \\
\hline $\begin{array}{l}\text { Top Weight } \\
\text { Ratio }\end{array}$ & TWR & - & $\frac{A B}{\mathrm{TPB}}$ & $\begin{array}{l}\text { The ratio of } \\
\text { above ground } \\
\text { dry weight } \\
\text { over the total } \\
\text { plant } \\
\text { biomass }\end{array}$ & $\begin{array}{l}\text { The } \\
\text { contribution of } \\
\text { aboveground } \\
\text { part to the } \\
\text { species } \\
\text { biomass at six } \\
\text { months } \\
\text { (sapling) as } \\
\text { response to } \\
\text { different } \\
\text { salinity and } \\
\text { sites }\end{array}$ & $\begin{array}{l}\text { Cuni } \\
\text { Sanchez et } \\
\text { al. (2011) }\end{array}$ \\
\hline $\begin{array}{l}\text { Shoot Root } \\
\text { Ratio }\end{array}$ & SRR & - & $\frac{A B}{\mathrm{RB}}$ & $\begin{array}{l}\text { The ratio of } \\
\text { aboveground } \\
\text { biomass over } \\
\text { the } \\
\text { belowground } \\
\text { biomass }\end{array}$ & $\begin{array}{l}\text { It gives an } \\
\text { idea of the } \\
\text { contribution of } \\
\text { leaves and } \\
\text { stem to the } \\
\text { species } \\
\text { biomass at six } \\
\text { months } \\
\text { (sapling) as } \\
\text { response to } \\
\text { different } \\
\text { salinity and } \\
\text { sites }\end{array}$ & $\begin{array}{l}\text { Cuni } \\
\text { Sanchez et } \\
\text { al. (2011) }\end{array}$ \\
\hline $\begin{array}{l}\text { Stem Weight } \\
\text { Ratio }\end{array}$ & SWR & - & ${ }_{\frac{\text { Dryweight }_{\text {stem }}}{\mathrm{TPB}}}$ & $\begin{array}{l}\text { The ratio of } \\
\text { stem dry } \\
\text { weight over } \\
\text { the total plant } \\
\text { biomass }\end{array}$ & $\begin{array}{l}\text { The } \\
\text { contribution of } \\
\text { stem to the } \\
\text { species } \\
\text { biomass at six } \\
\text { months } \\
\text { (sapling) }\end{array}$ & $\begin{array}{l}\text { Cuni } \\
\text { Sanchez et } \\
\text { al. (2011) }\end{array}$ \\
\hline
\end{tabular}




\begin{tabular}{|c|c|c|c|c|c|c|}
\hline $\begin{array}{l}\text { Growth } \\
\text { parameters }\end{array}$ & Symbol & Unit & Formula for calculation & $\begin{array}{l}\text { Description of } \\
\text { formula }\end{array}$ & $\begin{array}{l}\text { Relevance of } \\
\text { the parameter/ } \\
\text { index for this } \\
\text { study }\end{array}$ & References \\
\hline $\begin{array}{l}\text { Root Weight } \\
\text { Ratio }\end{array}$ & RWR & - & $\frac{\text { Dryweight }_{\text {roots }}}{{ }_{\mathrm{TPB}}}$ & $\begin{array}{l}\text { The ratio of } \\
\text { total roots dry } \\
\text { weight over } \\
\text { the total plant } \\
\text { biomass }\end{array}$ & $\begin{array}{l}\text { The } \\
\text { contribution of } \\
\text { roots to the } \\
\text { species } \\
\text { biomass at six } \\
\text { months } \\
\text { (sapling) as } \\
\text { response to } \\
\text { different } \\
\text { salinity and } \\
\text { sites }\end{array}$ & $\begin{array}{l}\text { Cuni } \\
\text { Sanchez et } \\
\text { al. (2011) }\end{array}$ \\
\hline Taproot Ratio & TPR & - & $\begin{array}{l}\text { Taprootlength } \\
\qquad \overline{\mathrm{Cb}}\end{array}$ & $\begin{array}{l}\text { The ratio } \\
\text { taproot length } \\
\text { divided its } \\
\text { basal } \\
\text { diameter }\end{array}$ & $\begin{array}{l}\text { It informs not } \\
\text { only on the } \\
\text { shape of the } \\
\text { taproot but } \\
\text { also on the } \\
\text { response of } \\
\text { the former to } \\
\text { different } \\
\text { salinity and } \\
\text { sites }\end{array}$ & $\begin{array}{l}\text { Cuni } \\
\text { Sanchez et } \\
\text { al. (2011) }\end{array}$ \\
\hline $\begin{array}{l}\text { Leaf Weight } \\
\text { Ratio }\end{array}$ & LWR & - & $\begin{array}{l}\text { Dryweight }_{\text {leaves }} \\
\mathrm{TPB}\end{array}$ & $\begin{array}{l}\text { The ratio of } \\
\text { total leaf dry } \\
\text { weight over } \\
\text { the total plant } \\
\text { biomass }\end{array}$ & $\begin{array}{l}\text { The } \\
\text { contribution of } \\
\text { leaves to the } \\
\text { species } \\
\text { biomass at six } \\
\text { months } \\
\text { (sapling) as } \\
\text { response of } \\
\text { seedlings to } \\
\text { different } \\
\text { salinity and } \\
\text { sites }\end{array}$ & $\begin{array}{l}\text { Cuni } \\
\text { Sanchez et } \\
\text { al. (2011) }\end{array}$ \\
\hline $\begin{array}{l}\text { Leaf water } \\
\text { content }\end{array}$ & LWC & $\%$ & Freshweightt leaves - Dryweight $_{\text {leaves }}$ & $\begin{array}{l}\text { The percent } \\
\text { water content } \\
\text { of stem } \\
\text { defined by its } \\
\text { wet weight } \\
\text { minus its dry } \\
\text { weight }\end{array}$ & $\begin{array}{l}\text { It informs on } \\
\text { water uptake } \\
\text { ability of } \\
\text { leaves }\end{array}$ & $\begin{array}{l}\text { Kodikara } \\
\text { et al. } 2018\end{array}$ \\
\hline $\begin{array}{l}\text { Stem Water } \\
\text { Content }\end{array}$ & SWC & $\%$ & Freshweightt $_{\text {stem }}-$ Dryweight $_{\text {stem }}$ & $\begin{array}{l}\text { The percent } \\
\text { water content } \\
\text { of stem } \\
\text { defined by its } \\
\text { wet weight } \\
\text { minus its dry } \\
\text { weight }\end{array}$ & $\begin{array}{l}\text { It informs on } \\
\text { water uptake } \\
\text { ability of stem }\end{array}$ & $\begin{array}{l}\text { Kodikara } \\
\text { et al. } 2018\end{array}$ \\
\hline $\begin{array}{l}\text { Root Water } \\
\text { Content }\end{array}$ & RWC & $\%$ & Freshweightt ${ }_{\text {roots }}-$ Dryweight $_{\text {roots }}$ & $\begin{array}{l}\text { The percent } \\
\text { water content } \\
\text { of all roots } \\
\text { defined by its } \\
\text { wet weight } \\
\text { minus its dry } \\
\text { weight }\end{array}$ & $\begin{array}{l}\text { It informs on } \\
\text { the water } \\
\text { uptake ability } \\
\text { of roots }\end{array}$ & $\begin{array}{l}\text { Kodikara } \\
\text { et al. } 2018\end{array}$ \\
\hline
\end{tabular}




\begin{tabular}{|c|c|c|c|c|c|c|}
\hline $\begin{array}{l}\text { Growth } \\
\text { parameters }\end{array}$ & Symbol & Unit & Formula for calculation & $\begin{array}{l}\text { Description of } \\
\text { formula }\end{array}$ & $\begin{array}{l}\text { Relevance of } \\
\text { the parameter/ } \\
\text { index for this } \\
\text { study }\end{array}$ & References \\
\hline $\begin{array}{l}\text { Leave } \\
\text { Morphology } \\
\text { Index }\end{array}$ & LMI & - & $\left(\sum_{i=1}^{3} \frac{\text { Lenght }_{i}}{\text { width }_{i}}\right) / 3$ & $\begin{array}{l}\text { The ratio of } \\
\text { length over } \\
\text { width of each } \\
\text { of the first } \\
\text { tree leaves of } \\
\text { each sapling }\end{array}$ & $\begin{array}{l}\text { It informs on } \\
\text { the shape of } \\
\text { the species } \\
\text { leave at the } \\
\text { sapling stage. } \\
\text { If LMI = } 1 \text {, then } \\
\text { leaves are said } \\
\text { round; when } \\
\text { LMI } 1 \text {, leaves } \\
\text { are considered } \\
\text { ovoid; and } \\
\text { when LMI > 1, } \\
\text { leaves are } \\
\text { described as } \\
\text { lanceolate }\end{array}$ & $\begin{array}{l}\text { Hounkpevi } \\
(2016)\end{array}$ \\
\hline $\begin{array}{l}\text { Specific Leaf } \\
\text { Area }\end{array}$ & SLA & & $\left(\sum_{i=1}^{3} \frac{\text { Surface }_{\text {section }_{i}}}{\text { Dryweight }_{\text {section }_{i}}}\right) / 3$ & $\begin{array}{l}\text { The ratio of } \\
\text { the widest } \\
\text { section } \\
\text { surface (first } \\
\text { three leaves) } \\
\text { by the dry } \\
\text { weight of the } \\
\text { section }\end{array}$ & $\begin{array}{l}\text { It informs on } \\
\text { the efficiency } \\
\text { of the use of } \\
\text { environmental } \\
\text { resources by } \\
\text { species, and } \\
\text { on site and } \\
\text { salinity } \\
\text { influence on } \\
\text { nutrient } \\
\text { uptake, } \\
\text { productivity } \\
\text { (mass-based } \\
\text { light-saturated } \\
\text { photosynthetic } \\
\text { rate), leaves } \\
\text { resilience to } \\
\text { stressors } \\
\text { (longevity), } \\
\text { and carbon } \\
\text { investment in } \\
\text { secondary dry } \\
\text { mass (tannin, } \\
\text { lignin, etc.). } \\
\text { The higher it } \\
\text { is, the lower is } \\
\text { the species } \\
\text { performance } \\
\text { (adaptation to } \\
\text { stressors and } \\
\text { efficient use of } \\
\text { resources) }\end{array}$ & $\begin{array}{l}\text { Gbeffe et } \\
\text { al. (2017) }\end{array}$ \\
\hline
\end{tabular}

All statistical analyses were implemented in R software version 3.5.1 (R Core Team 2018).

\section{Results}

\section{Survival}

After the 5th month, due to an unexpected management to take place at the site of Djègbamey, we were no longer able to collect data on this site. Only site had a significant effect $(p<0.001)$ on the survival rate of seedlings. Salinity under which the propagules emerged did affect $(p>0.05)$ survival neither as main factor nor in the interaction (Table 3$)$. At the end of the month five, survival rates were $75.30 \%$ and $75.50 \%$ for individuals raised under low and medium salinities, respectively. With regards to sites, survival rate was relatively higher at sites of Azizakouè (87.50\%) and Djègbamey (77.30\%) as compared to Lanhou (62.40\%) (Fig. 2). 
Table 3

Effects of salinity and site on the survival seedlings: results of the survival model based on the Kaplan-Mayer method

\begin{tabular}{|lccl|}
\hline Source of variation & df & Chisq & $P$ \\
\hline Site & 2 & 13.83 & $<0.001$ \\
\hline Salinity & 1 & 1.23 & 0.268 \\
\hline Site: Salinity & 2 & 4.95 & 0.084 \\
\hline$d f:$ degree of freedom; Chisq: $\chi^{2}$ statistic; p: probability of significance \\
\hline
\end{tabular}

\section{Growth}

To be able to compare all three sites, estimation of growth trends considered data until the end of the 5th month (Fig. 3). On average, the total height was $60.54 \mathrm{~cm} \pm 1.53$ and $61.05 \mathrm{~cm} \pm 1.64$ for individuals raised under low and medium salinities, respectively. Regarding sites, average total height was $63.00 \mathrm{~cm} \pm 1.59,58.29 \mathrm{~cm} \pm 1.37$, and $64.57 \mathrm{~cm} \pm 2.73$ for Azizakouè, Djègbamey, and Lanhou, respectively. There was significant effect of the interactions of time with salinity $(p=0.017)$ and site $(p=0.045)$ on the plant total height, indicating that growth trends in total height across time differed among salinity levels and sites. However, the main effect of salinity was not significant contrary to that of time and site $(p>0.05)$ (Table 4$)$. Growth speed was lower with seedlings raised under medium salinity (estimate $=-5.12$, se $=2.15, t=-2.38, \mathrm{df}=791, p=0.017$ ) compared to seedlings raised under low salinity. The lowest total height of seedlings was recorded on Lanhou site (estimate $=-16.87$, se $=7.06, t=-2.39, \mathrm{df}=791, p=0.017$ ) while statistically similar for Djègbamey and Azizakouè sites (Fig. 3). Nevertheless, growth speed was relatively lower at the Djègbamey site (estimate $=-4.33$, se $=2.19, t=-1.98, \mathrm{df}=791, p=0.048$ ) compared to Azizakouè.

Table 4

Effects of salinity and site on plant total height and number of leaves of $R$. racemosa: results of LMM and GLMM on longitudinal data

\begin{tabular}{|llllll|}
\hline Source of variation & Df & \multicolumn{2}{l}{ Plant total height } & \multicolumn{2}{l|}{ Number of leaves } \\
\cline { 2 - 6 } & & Chisq & $\boldsymbol{P}$ & Chisq & $\boldsymbol{P}$ \\
\hline Time & 1 & 35.39 & $<0.001$ & 0.00 & 0.979 \\
\hline Salinity & 1 & 3.51 & 0.061 & 37.48 & $<0.001$ \\
\hline Site & 2 & 11.25 & 0.004 & 3.48 & 0.175 \\
\hline Time : Salinity & 1 & 5.68 & 0.017 & 14.68 & $<0.001$ \\
\hline Time : Site & 2 & 6.19 & 0.045 & 1.82 & 0.402 \\
\hline Salinity : Site & 2 & 2.16 & 0.338 & 23.82 & $<0.001$ \\
\hline Time : Salinity : Site & 2 & 4.35 & 0.114 & 11.68 & 0.003 \\
\hline ICC Bloc (\%) & & & $\mathbf{5 . 4 0}$ & & $\mathbf{1 5 . 1 8}$ \\
\hline df : degree of freedom ; Chisq : $\chi^{2}$ statistic ; $p:$ probability of significance ; ICC : Intra Class correlation \\
\hline
\end{tabular}

At the end of the 5 th month, the total number of leaves were $24.02 \pm 0.47$ and $25.57 \pm 0.62$ for individuals raised under low and medium salinities, respectively. With regards to sites, average numbers of leaves were $24.93 \pm 0.59,24.46 \pm 0.66$, and $25.09 \pm 0.85$ for the sites of Lanhou, Djègbamey, and Azizakouè, respectively. Significant interaction $(p=0.003)$ was detected between time, salinity, and site; indicating that the evolution of leaves production across time differed among sites and salinity levels. In general, the number of leaves was significantly higher for individuals raised under medium salinity levels (estimate $=12.00, \mathrm{se}=1.96, \mathrm{df}=$ 791 , chisq $=6.12, p<0.001$ ). Though not significant, the number of leaves was highest at Azizakouè, the more saline site (Fig. 4). Further analyses conducted per site due to the significant interaction of the three factors showed that neither the main effect of salinity nor its interaction with time were significant $(p>0.05)$ at Djègbamey and Lanhou sites. On the contrary, at Azizakouè, the 
trend of the number of leaves was comparatively lower for seedlings raised under medium salinity $(e s t i m a t e=-2.34$, se $=0.80$, $\mathrm{df}=$ 273, chisq $=-2.92, p=0.004$ ) (Fig. 4).

\section{Biomass}

Only sites of Azizakouè and Lanhou were considered for biomass estimation due to restriction of access to the site of Djègbamey at the end of the experiment. Table 5 summarizes variation of structural parameters and productivity indices in relationships to watering salinity in nursery and sites at the end of month six.

Table 5 Variation of productivity indices in relationships to watering salinity in nursery and sites: mean ( $\mathrm{m}$ ) \pm standard error (se) of indices, $\mathrm{p}$-values from mixed effects models $(p)$ and intra-class correlation due to bloc effect $\left(\right.$ ICC $\left._{\mathrm{Bloc}}\right)$ 


\begin{tabular}{|c|c|c|c|c|c|c|c|c|}
\hline \multirow{3}{*}{$\begin{array}{l}\text { Growth and productivity } \\
\text { indices }\end{array}$} & \multicolumn{3}{|c|}{ Salinity of watering in nursery } & \multicolumn{3}{|l|}{ Sites } & \multirow{3}{*}{$\begin{array}{l}p_{\text {Salinity: }} \\
\text { Site }\end{array}$} & \multirow{3}{*}{$\begin{array}{l}\text { ICC } \\
\text { Bloc }\end{array}$} \\
\hline & Low & Medium & $P$ & $\begin{array}{l}\text { Azizakouè } \\
\text { (High) }\end{array}$ & $\begin{array}{l}\text { Lanhou } \\
\text { (Low) }\end{array}$ & $p$ & & \\
\hline & $\mathrm{m} \pm \mathrm{se}$ & $\mathrm{m} \pm \mathrm{se}$ & & $\mathrm{m} \pm \mathrm{se}$ & $\mathrm{m} \pm \mathrm{se}$ & & & \\
\hline Plant total height: $\mathrm{Ht}$ (cm) & $\begin{array}{l}75.72 \mathrm{a} \pm \\
1.79\end{array}$ & $\begin{array}{l}75.74 a \pm \\
2.35\end{array}$ & 0.272 & $72.33 b \pm 1.64$ & $\begin{array}{l}79.13 a \pm \\
2.29\end{array}$ & 0.007 & 0.125 & 0.00 \\
\hline Hypocotyl height: Hh (cm) & $\begin{array}{l}29.24 \mathrm{a} \pm \\
1.50\end{array}$ & $\begin{array}{l}31.10 \mathrm{a} \pm \\
2.00\end{array}$ & 0.305 & $34.61 a \pm 2.00$ & $\begin{array}{l}25.72 b \pm \\
0.97\end{array}$ & 0.017 & 0.542 & 7.81 \\
\hline $\begin{array}{l}\text { Basal circumference: } \mathrm{Cb} \\
(\mathrm{cm})\end{array}$ & $\begin{array}{l}5.70 \mathrm{a} \pm \\
0.12\end{array}$ & $\begin{array}{l}5.95 \mathrm{a} \pm \\
0.15\end{array}$ & 0.160 & $5.97 a \pm 0.14$ & $\begin{array}{l}5.68 \mathrm{a} \pm \\
0.13\end{array}$ & 0.542 & 0.501 & 1.06 \\
\hline $\begin{array}{l}\text { Total Plant Biomass: TPB } \\
\text { (g) }\end{array}$ & $\begin{array}{l}34.84 \mathrm{a} \pm \\
1.21\end{array}$ & $\begin{array}{l}37.69 \mathrm{a} \pm \\
3.59\end{array}$ & 0.494 & $37.36 a \pm 2.54$ & $\begin{array}{l}35.17 a \pm \\
2.87\end{array}$ & 0.598 & 0.993 & 0.00 \\
\hline Aerial Biomass: AB (g) & $\begin{array}{l}23.42 \mathrm{a} \pm \\
0.87\end{array}$ & $\begin{array}{l}26.36 \mathrm{a} \pm \\
2.44\end{array}$ & 0.307 & $24.54 a \pm 1.77$ & $\begin{array}{l}25.24 \mathrm{a} \pm \\
2.10\end{array}$ & 0.808 & 0.307 & 0.00 \\
\hline Root Biomass: RB (g) & $\begin{array}{l}11.42 \mathrm{a} \pm \\
0.95\end{array}$ & $\begin{array}{l}11.33 a \pm \\
1.28\end{array}$ & 0.942 & $12.82 \mathrm{a} \pm 0.94$ & $\begin{array}{l}9.93 b \pm \\
0.90\end{array}$ & 0.023 & 0.588 & 21.71 \\
\hline Top Weight Ratio: TWR & $\begin{array}{l}0.21 \mathrm{a} \pm \\
0.01\end{array}$ & $\begin{array}{l}0.17 b \pm \\
0.00\end{array}$ & 0.001 & $0.20 a \pm 0.02$ & $\begin{array}{l}0.18 \mathrm{a} \pm \\
0.01\end{array}$ & 0.067 & 0.021 & 7.50 \\
\hline Shoot Root Ratio: SRR & $\begin{array}{l}2.18 \mathrm{~b} \pm \\
0.23\end{array}$ & $\begin{array}{l}2.56 \mathrm{a} \pm \\
0.12\end{array}$ & 0.004 & $2.05 b \pm 0.14$ & $\begin{array}{l}2.69 \mathrm{a} \pm \\
0.14\end{array}$ & 0.001 & 0.127 & 33.41 \\
\hline Stem Weight Ratio: SWR & $\begin{array}{l}0.49 \mathrm{~b} \pm \\
0.02\end{array}$ & $\begin{array}{l}0.55 \mathrm{a} \pm \\
0.01\end{array}$ & 0.004 & $0.46 b \pm 0.02$ & $\begin{array}{l}0.54 \mathrm{a} \pm \\
0.02\end{array}$ & 0.036 & 0.159 & 3.33 \\
\hline Root Weight Ratio: RWR & $\begin{array}{l}0.33 a \pm \\
0.02\end{array}$ & $\begin{array}{l}0.29 b \pm \\
0.00\end{array}$ & 0.001 & $0.34 a \pm 0.02$ & $\begin{array}{l}0.28 \mathrm{~b} \pm \\
0.01\end{array}$ & 0.001 & 0.024 & 17.86 \\
\hline Taproot Ratio: TRR & $\begin{array}{l}9.18 \mathrm{a} \pm \\
0.58\end{array}$ & $\begin{array}{l}9.28 \mathrm{a} \pm \\
0.72\end{array}$ & 0.903 & $8.90 a \pm 0.67$ & $\begin{array}{l}9.57 a \pm \\
0.61\end{array}$ & 0.448 & 0.110 & 0.00 \\
\hline Leaf Weight Ratio: LWR & $\begin{array}{l}0.18 \mathrm{a} \pm \\
0.01\end{array}$ & $\begin{array}{l}0.16 \mathrm{a} \pm \\
0.01\end{array}$ & 0.155 & $0.16 a \pm 0.01$ & $\begin{array}{l}0.18 \mathrm{a} \pm \\
0.01\end{array}$ & 0.434 & 0.775 & 0.00 \\
\hline $\begin{array}{l}\text { Leaf Water Content: LWC } \\
\text { (\%) }\end{array}$ & $\begin{array}{l}65.75 \mathrm{a} \pm \\
2.28\end{array}$ & $\begin{array}{l}64.36 \mathrm{a} \pm \\
3.36\end{array}$ & 0.736 & $66.14 a \pm 3.59$ & $\begin{array}{l}63.98 \mathrm{a} \pm \\
1.83\end{array}$ & 0.603 & 0.245 & 0.00 \\
\hline $\begin{array}{l}\text { Stem Water Content/ SWC } \\
(\%)\end{array}$ & $\begin{array}{l}65.83 a \pm \\
1.58\end{array}$ & $\begin{array}{l}62.65 a \pm \\
1.27\end{array}$ & 0.062 & $65.61 a \pm 1.45$ & $\begin{array}{l}62.87 a \pm \\
1.50\end{array}$ & 0.106 & 0.384 & 26.34 \\
\hline $\begin{array}{l}\text { Root Water Content: RWC } \\
(\%)\end{array}$ & $\begin{array}{l}71.38 \mathrm{a} \pm \\
1.09\end{array}$ & $\begin{array}{l}72.20 \mathrm{a} \pm \\
1.94\end{array}$ & 0.737 & $71.23 a \pm 2.01$ & $\begin{array}{l}72.36 a \pm \\
0.91\end{array}$ & 0.646 & 0.858 & 0.00 \\
\hline $\begin{array}{l}\text { Leaf Morphology Index: } \\
\text { LMI }\end{array}$ & $\begin{array}{l}3.86 a \pm \\
0.14\end{array}$ & $\begin{array}{l}3.74 \mathrm{a} \pm \\
0.27\end{array}$ & 0.695 & $3.86 a \pm 0.23$ & $\begin{array}{l}3.74 a \pm \\
0.20\end{array}$ & 0.695 & 0.184 & 0.00 \\
\hline Specific Leaf Area: SLA & $\begin{array}{l}64.88 \mathrm{a} \pm \\
5.15\end{array}$ & $\begin{array}{l}61.19 a \pm \\
2.68\end{array}$ & 0.498 & $67.70 a \pm 5.03$ & $\begin{array}{l}58.37 a \pm \\
1.00\end{array}$ & 0.086 & 0.510 & 0.00 \\
\hline
\end{tabular}

Only two sites (Azizakouè and Lanhou) are considered for growth and productivity (instead of 3 as shown by figure 1 and 3) because after the $5^{\text {th }}$ month, due to an unexpected management to take place at the Djègbamey site, we were no longer able to collect data on this site.

Salinity treatment received by the propagules at the emergence stage had significant effect $(p<0.05)$ on weight ratio indices, namely shoot root ratio, stem weight ratio, root weight ratio, and top weight ratio. Site had significant effect $(p<0.05)$ on structural parameters - - total height and hypocotyls height, but also productivity indices -- root biomass, shoot root ratio, stem weight ratio, and root weight ratio. The interaction between salinity and site was significant only for root weight ratio (RWR, $p<0.024)$ and top weight ratio (TWR, $p<0.021$ ), indicating that the difference between salinity levels for these ratios was not similar between the two sites. The other parameters and indices did not vary neither with salinity nor with sites (Table 5). 
The total plant biomass and the aerial biomass were on average $36.27 \mathrm{~g} \pm 12.62 \mathrm{~g}$ and $24.89 \mathrm{~g} \pm 1.31$, respectively. The root biomass was on average $11.37 \mathrm{~g} \pm 0.76$ and was 1.3 times higher at Azizakouè than at Lanhou. The top weight ratio was on average $0.19 \pm$ 0.01 and was higher for seedlings raised with low salinity. Shoot Root Ratio (SRR) and Stem Weight Ratio (SWR) were on average $2.37 \pm 0.77$ and $0.52 \pm 0.02$ respectively and were higher for seedlings raised with low water salinity and at the site of Lanhou. SRR values greater than 1 for both sites indicate that from seedling to sapling stages, $R$. racemosa invest more in the development of aerial biomass. Higher value of SRR at Lanhou $(2.69 \pm 0.14)$ indicates that saplings of this site invested more in aerial biomass than in roots contrary to saplings of Azizakouè $(2.05 \pm 0.14)$ which invested relatively more in the development of their root system. The mean value of SRR also indicates that from seedling to sapling stages, individuals of $R$. racemosa invest 2 times more in aboveground biomass production than in below ground biomass. The root weight ratio (RWR) was on average $0.31 \pm 0.01$ and was higher for seedlings raised with low water salinity and at the site of Azizakouè, confirming that seedlings of Azizakouè invested more in the development of their root systems than those of Lanhou. The taproot ratio (TRR) and the leaf weight ratio (LWR) were on average $9.23 \pm 2.66$ and $0.17 \pm 0.01$. The value of the taproot ratio $(>1)$ indicates that at this stage of life cycle, roots of $R$. racemosa are already very deep in the substrate.

There was a significant positive relationship between above and below ground biomasses $(F=63.16, d f=1, p<0.001$, Table 6$)$. The interaction of below-ground biomass with site was significant $(F=7.56, \mathrm{df}=1, p=0.008)$ contrary to the interaction with salinity that was not significant $(\mathrm{F}=0.68 \mathrm{df}=1, p=0.413)$, indicating shifting pattern of biomass allocation between above- and below- ground across sites, but not salinities. Specifically, the Lanhou site had a significantly higher slope compared to Azizakouè site $(p=0.008$, Table 6 and Fig. 5). The equations established per site showed that the slope was $0.94(\mathrm{Cl}=[0.47 ; 1.41])$ for Azizakouè site (Aboveground biomass $=12.48+0.94$ Below-ground biomass, $\left.R^{2}=0.38\right)$ and $1.86(\mathrm{Cl}=[1.39 ; 2.41])$ for Lanhou site (Above-ground biomass $=6.41+1.86$ Below-ground biomass; $\left.R^{2}=0.67\right)(F i g .5)$. Confidence intervals showed that the slope for Azizakouè site was statistically not different from one whereas the slope at Lanhou site was greater than one indicating isometric relationship at Azizakouè site and non-isometric relationship at Lanhou site.

Table 6

Variation of the relationships between above- and below- ground across salinities and sites: results of the linear models $\left(R^{2}=0.58, F=14.98, D f=5\right.$ on $54, p=$ $3.26 \mathrm{e}-09)$

\begin{tabular}{|llllll|}
\hline Sources of variation & Estimate & $\mathbf{s e}$ & $\mathbf{C l}$ & t-value & $\mathbf{p}$ \\
\hline (Intercept) & 13.83 & 4.71 & {$[4.39 ; 23.28]$} & 2.935 & 0.005 \\
\hline Below & 0.72 & 0.36 & {$[-0.01 ; 1.44]$} & 1.976 & 0.053 \\
\hline SitesLanhou & -6.20 & 4.15 & {$[-14.52 ; 2.11]$} & -1.496 & 0.140 \\
\hline SalinityMedium & -0.73 & 4.49 & {$[-9.74 ; 8.28]$} & -0.162 & 0.872 \\
\hline Below:SitesLanhou & 0.94 & 0.34 & {$[0.25 ; 1.62]$} & 2.75 & 0.008 \\
\hline Below:SalinityMedium & 0.30 & 0.37 & {$[-0.44 ; 1.05]$} & 0.825 & 0.413 \\
\hline
\end{tabular}

Up to six months after emergence, the water content of $R$. racemosa individuals was higher than its accumulated biomass (Fig. 6). For the whole plant, water content percentage is about $2 / 3$ of the total plant weight in Lanhou (Fig. 6b) and much higher at Azizakouè site (Fig. 6a). For all plant parts, water content was higher at Azizakouè than at Lanhou, indicating that site plays important role in water uptake and biomass productivity of seedlings of $R$. racemosa. Results on biomass partitioning among leaves, stem, and roots, indicated that about half of the total biomass $(45-54 \%)$ is stored in stems, followed by roots $(28-37 \%)$, and lastly leaves $(15-18 \%)$ (Fig. 7).

Besides, Leaf Morphology Index (LMI) was on average $3.93 \pm 2.46$ and was greater than 1 (Table 5) indicating that leaves of $R$. racemosa are lanceolate. The Specific Leaf Area (SLA) was on average $63.33 \pm 14.91 \mathrm{~cm}^{2} / \mathrm{g}$ indicating that about $63 \mathrm{~cm}^{2}$ of leaves of $R$. racemosa correspond to $1 \mathrm{~g}$ of dry biomass at this stage.

\section{Discussion}


Abiotic factors such as light, slope, substrates physical structure and chemical composition are determinant for the emergence, growth, distribution, and survival of mangrove species (Dasgupta et al. 2017; Khan and Aziz 2001). Several studies have also reported site salinity as a key factor influencing the survival, establishment, growth, and productivity of mangrove species (Amores et al. 2013; Ball and Pidsley 1995; Vovides et al. 2018; and Lambs et al. 2008). Other studies have demonstrated that salinity of water in nursery greatly influences emergence and early growth of mangrove species (Chen and Ye 2014; Saha et al. 2014). However, we still know little on the effects of salinity (salinity under which propagules emerged in nursery) on survival and productivity performances after transplantation of seedlings, particularly for mangrove species from West-Africa. This study is to our knowledge, the first one to report on this in a less studied mangrove zone such as West-Africa. The study used the case study of $R$. racemosa which is one of the most common true mangrove species in the region.

Survival of seedlings after transplantation was not influenced by salinity in nursery but rather by site, the survival rate being higher in sites with higher salinities $(87.50 \%, 77.30 \%$, and $62.40 \%$ for sites with mean salinity values of $18.16 \pm 0.46 \mathrm{psu}, 11.60 \pm 1.14 \mathrm{psu}$, and $4.60 \pm 1.78$, respectively). This implies that salinity of transplantation site overrules salinity under which seedlings were raised in nursery, as far as seedling survival is concerned. Thus, corroborating previous findings that transplantation salinity is key for the survival of transplanted seedlings. Some authors, e.g., Clarke and Allaway (1993) further consider that survival of mangroves' seedlings/saplings depend only on tidal/wave action. The non-significance of water salinity used in nursery (3-5 versus 15-17 psu) on seedling survival after transplantation may suggest a lack of salinity shock vis-à-vis salinity of transplantation sites and that prior acclimation of seedlings from nursery is not needed in such conditions. Raising seedling of Xylocarpus granatum J. König (Meliaceae), one of the most valuable mangrove tree species of the Sundarbans with plain water and transplanting in polyethylene bag with various water salinity, Siddique et al. (2017) rather found negative correlation of salinity (range: $0-35$ psu) and survival rate. The positive correlation we found can be due to the combined effect of raising seedlings with non-hypersaline water i.e., 3-5 and 15-17 psu that might have prepared seedlings to cope with the salinity in transplantation site which can also be considered moderate (<20 psu). We might have observed decreased survival if the study included sites with hypersaline condition up to or even higher than $35 \mathrm{psu}$ (seawater salinity). Considering higher values of salinity will certainly provide additional insights into effect of salinity at transplantation site on seedlings survival. The difference with findings of Siddique et al. (2017) might also be due to species-specific response. In fact, although it has been suggested that optimum salinity for growth of mangrove species generally ranges from 5 to $50 \%$ seawater (Ball 1988), there is a large variation in species response to salinity; while some are facultative halophyte, others are obligate halophyte (Wang et al. 2011). It might however also be plausible that other environmental factors (e.g., nutrients availability) that differ among the sites interfere with the effect of site salinity.

Concerning growth parameters, the site with the lowest salinity had the lowest growth in height, especially, during the first three months, suggesting that sites of moderate salinity favour growth in height of $R$. racemosa seedlings after transplantation. On the opposite, variation in the number of leaves was not influenced by salinity of transplantation site. We rather found that while salinity in the nursery was not important on Lanhou and Djègbamey sites (low to moderate saline sites), seedlings raised with moderate water salinity in nursery had higher number of leaves than seedlings raised with low water salinity in the more saline site of Azizakouè. Therefore, depending on the salinity of the transplantation site, salinity in nursery may result into differential growth performance. The low performance of seedlings raised with low salinity in this site could be linked to the difference with salinity of the transplantation site, and thus highlights that in case of a greater gap between salinity in nursery and that of transplantation site, seedlings might not perform well, and hence require a sufficient acclimation period before.

Although our study suggests positive correlation between site salinity and growth of mangrove species, some authors found negative correlation between salinity and growth of mangrove species. For instance, salinity of 25 psu in nursery conditions was found to be lethal for the growth of Xylocarpus granatum (Siddique et al. 2017). Since salt tolerance is species specific (Ye et al. 2005) and age dependent (Kodikara et al. 2018), divergence of correlation trends may be linked to species identity and life stage of individuals considered in experiments. Beyond salinity, site nutrient composition is a possible cause of the differing growth patterns among sites (Chen and Ye 2014). Also, flood events (which occurred just three days after transplantation) could explain the low growth performance at Lanhou. As a response to the sudden water logging, individuals of $R$. racemosa might have invested in root strengthening (instead of aerial growth) as to increase their likelihood to survive whereas rapid growth in height and number of leaves following water recessed could be the expression of efficient extraction of nutrients brought to the soil by the tides. Besides, transplantation period could justify the observed low growth and survival rates as it was done at the end of the dry season/beginning of the longest rainy season. Seedlings might not have enough time to well establish their roots before rains start

Page $13 / 17$ 
and might have easily been uprooted by inundation of substrates and strong water flow (e.g., Lanhou site). Relating transplantation period to growth and survival rates, we could recommend restoration through plantation of seedlings from nursery not to be done on the eve of rainy season even if Kodikara et al. (2018) suggested eve of rainy season to favour the establishment of seedlings and to be suitable for restoration from nursery. We argue that while restoration on the eve of rainy season may help controlling the salinity through dilution, and thus favour seedling growth, it is equally important that seedlings have strong rooting system to thrive high water currents due to rainy season. In our study area, we observed higher growth in total height, but no clear trend for the change in the number of leaves for individuals of $R$. racemosa at the most saline site (Azizakouè). This pattern may be because sixty days after planting, the leaves were attacked by Phytophagus sp (caterpillar, Fig. 8) which caused massive loss of leaves. With this parasitic attack, plants might have slackened their growth rate in order to develop resistance mechanism and possibly invest more in renewing lost leaves (Ellison and Farnsworth 1993).

Characteristics of transplantation site, including salinity lead nutrient uptake, conductance through the xylem, and can affect productivity of the plants (Biber, 2006; Chen and Ye 2014). As salinity increases, many mangrove species reduce the intake of salt, and consequently, of water and nutrients, and require greater allocation of biomass to root growth, thus contributing to a higher root/shoot ratio in more saline environments (Naidoo 2016). In this study, although total biomass and aerial biomass did not vary neither with water salinity in nursery nor with sites, our finding of higher root biomass and root weight ratio in the site with highest water salinity (Azizakouè) does supports the point that mangrove species tend to allocate more biomass to root to adapt to higher salinity conditions. These results therefore imply that salinity represents a stressor which affects biomass partitioning of $R$. racemosa at juvenile stage. Water represents approximately $2 / 3$ of the total plant weight and seems to be slightly higher in Lanhou site (less saline site) compared to Azizakouè (more saline site). Moreover, stem, root, and leaves in this order stored more biomass confirming the assumption of the existence of trade-offs in biomass allocation to roots, leaves, and stem functions as suggested by the optimal partitioning theory (Mccarthy and Enquist 2007).

These findings suggest that $R$. racemosa first solidifies its root system in the substrate followed by investment in growth (height, leaves). This is consistent with the description of Rhizophora spp by Duke and Allen (2006).

\section{Conclusion}

Survival, growth, and productivity of transplanted $R$. racemosa from nursery are not mainly influenced by salinity treatment received by propagules, but rather by site and the interaction of the two factors. Salinity treatment received at nursery should then be carefully chosen with consideration of salinity conditions of restoration sites. It is recommended that restoration activities are planned in appropriate period, ideally one month before the beginning of rainy season not only to allow seedling to well solidify their rooting system in the substrate before rains start, but also to favour seedlings growth, because of substrate salinity dilution by fresh water from rains and flow from uplands. Repeating our experiment with a larger range of salinity would provide additional insights for successful restoration through transplantation.

\section{Declarations}

\section{Funding}

The authors declare that no funds, grants, or other support were received during the preparation of this manuscript.

\section{Competing Interests}

"The authors have no relevant financial or non-financial interests to disclose."

\section{Ethics Approval}

Not applicable.

\section{Consent for Publication}

Not applicable. 
SCBL and SKV conceived and designed the study with advice from GKR. SCBL collected the data with the support of SKV. SCBL, TRJ and SKV processed the data and performed the statistical analyses. SCBL and SKV wrote the initial draft of the manuscript and all authors commented on previous versions of the manuscript. All authors read and approved the final manuscript.

\section{Data Availability}

The datasets generated during and/or analysed during the current study are available from the corresponding author on reasonable request.

\section{References}

1. Amores MJ, Verones F, Raptis C, Juraske R, Pfister S, Stoessel F, Antón A, Castells F, Hellweg S (2013) Biodiversity Impacts from Salinity Increase in a Coastal Wetland. Environ. Sci. Technol. 47, 6384-6392. https://doi.org/10.1021/es3045423

2. Ball MC, Pidsley SM (1995) Growth Responses to Salinity in Relation to Distribution of Two Mangrove Species, Sonneratia alba and S. lanceolata, in Northern Australia. Funct. Ecol. 9, 77-85. https://doi.org/10.2307/2390093

3. Biber PD (2006) Measuring the effects of salinity stress in the red mangrove, Rhizophora mangle L. Afr. J. Agric. Res. 1, 1.

4. Chen Y, Ye Y (2014) Effects of Salinity and Nutrient Addition on Mangrove Excoecaria agallocha. Plos One 9, e93337. https://doi.org/10.1371/journal.pone.0093337

5. Clarke PJ, Allaway WG (1993) The regeneration niche of the grey mangrove (Avicennia marina): effects of salinity, light and sediment factors on establishment, growth and survival in the field. Oecologia 93, 548-556. https://doi.org/10.1007/BF00328964

6. Clough BF (1992) Primary productivity and growth of mangrove forests, in: Robertson, A.I., Alongi, D.M. (Eds.), Coastal and Estuarine Studies. American Geophysical Union, Washington, D. C., pp. 225-249. https://doi.org/10.1029/CE041p0225

7. Cuni Sanchez A, De Smedt S, Haq N, Samson R (2011) Variation in baobab seedling morphology and its implications for selecting superior planting material. Sci. Hortic. 130, 109-117. https://doi.org/10.1016/j.scienta.2011.06.021

8. Dasgupta S, Sobhan I, Wheeler D (2017) The impact of climate change and aquatic salinization on mangrove species in the Bangladesh Sundarbans. Ambio 46, 680-694. https://doi.org/10.1007/s13280-017-0911-0

9. Duke NC (1991) A systematic revision of the mangrove genus Avicennia (Avicenniaceae) in Australasia. Aust. Syst. Bot. 4, 299324.

10. Duke NC, Allen JA (2006) Rhizophora mangle, R. samoensis, R. racemosa, R. harrisonii (Atlantic-East Pacific red mangrove). Species profiles for Pacific island agroforestry 10, 1-18.

11. Ellison AM, Farnsworth EJ (1993) Seedling Survivorship, Growth, and Response to Disturbance in Belizean Mangal. Am. J. Bot. 80, 1137-1145. https://doi.org/10.2307/2445541

12. Gbeffe AK, Houehanou TD, Habiyaremye M, Assede ES, Yaoitcha AS, Janssens de Bisthoven L, Sogbohossou EA, Houinato M, Sinsin BA (2017) Effects of termite mounds on composition, functional types and traits of plant communities in Pendjari Biosphere Reserve (Benin, West Africa). Afr. J. Ecol. 55, 580-591.

13. Khan MA, Aziz I (2001) Salinity tolerance in some mangrove species from Pakistan. Wetl. Ecol. Manag. 9, $229-233$. https://doi.org/10.1023/A:1011112908069

14. Kobe RK, lyer M, Walters MB (2010) Optimal partitioning theory revisited: nonstructural carbohydrates dominate root mass responses to nitrogen. Ecology, 91(1), 166-179.

15. Kodikara KAS, Jayatissa LP, Huxham M, Dahdouh-Guebas F, Koedam N, Kodikara KAS, Jayatissa LP, Huxham M, DahdouhGuebas F, Koedam N (2018) The effects of salinity on growth and survival of mangrove seedlings changes with age. Acta Bot. Brasilica 32, 37-46. https://doi.org/10.1590/0102-33062017abb0100

16. Kuznetsova A, Brockhoff PB, Christensen RHB (2019) ImerTest: Tests in Linear Mixed Effects Models.

17. Lambs L, Muller E, Fromard $F$ (2008) Mangrove trees growing in a very saline condition but not using seawater. Rapid Communications in Mass Spectrometry 22, 2835-2843. https://doi.org/10.1002/rcm.3676 
18. Mccarthy MC, Enquist BJ (2007) Consistency between an allometric approach and optimal partitioning theory in global patterns of plant biomass allocation. Funct Ecol. 21, 713-720. https://doi.org/10.1111/j.1365-2435.2007.01276.x

19. Naidoo G (2016). The mangroves of South Africa: An ecophysiological review. S. Afr. J. Bot. 107, 101-113.

20. Onofri A, Gresta F, Tei F (2010) A new method for the analysis of germination and emergence data of weed species: Survival analysis for germination and emergence data. Weed Res. 50, 187-198. https://doi.org/10.1111/j.1365-3180.2010.00776.x

21. Pinheiro J, Bates D, DebRoy S, Sarkar DE, Heisterkamp S, Van Willigen B, R-core Team (2018) nlme: Linear and Nonlinear Mixed Effects Models.

22. Saenger $P$ (1995) The mangrove vegetation of the Atlantic Coast of Africa: a review. Southern Cross University, School of Environment, Science and Engineering.

23. Saha S, Hossain M, Salekin S, Mamun A-A, Siddique MRH, Abdullah SMR (2014) Salinity Influence On Germination Of Four Important Mangrove Species Of The Sundarbans, Bangladesh. Agric. For. 60, 125-135.

24. Siddique M, Saha S, Salekin S, Mahmood H (2017) Salinity strongly drives the survival, growth, leaf demography, and nutrient partitioning in seedlings of Xylocarpus granatum J. König. iForest - Biogeosciences and Forestry 10, 851-856. https://doi.org/10.3832/ifor2382-010

25. Singer JD, Willett JB (2003) Applied longitudinal data analysis: Modeling change and event occurrence, Applied longitudinal data analysis: Modeling change and event occurrence. Oxford University Press, New York, NY, US. https://doi.org/10.1093/acprof:oso/9780195152968.001.0001

26. Stern WL, Voigt GK (1959) Effect of Salt Concentration on Growth of Red Mangrove in Culture. Botanical Gazette 121, 36-39. https://doi.org/10.1086/336039

27. Therneau TM, Grambsch PM (2000) Modeling survival data: extending the Cox model, Statistics for biology and health. Springer, New York.

28. Venables WN, Ripley BD (2002). Modern Applied Statistics with S, Fourth edition. Springer, New York. ISBN 0-387-954570, http://www.stats.ox.ac.uk/pub/MASS4/.

29. Vovides AG, Berger U, Grueters U, Guevara R, Pommerening A, Lara-Domínguez AL, López-Portillo J (2018). Change in drivers of mangrove crown displacement along a salinity stress gradient. Func. Ecol. 32, 2753-2765.

30. Wang W, Yan Z, You S, Zhang Y, Chen L, Lin G (2011) Mangroves: obligate or facultative halophytes? A review. Trees 25, $953-$ 963. https://doi.org/10.1007/s00468-011-0570-x

31. Ye Y, Tam NF-Y, Lu C-Y, Wong Y-S (2005) Effects of salinity on germination, seedling growth and physiology of three saltsecreting mangrove species. Aquat. Bot. 83, 193-205.

\section{Figures}

\section{Figure 1}

Map showing the experimentation sites

\section{Figure 2}

Survival patterns of $R$. racemosa seedlings across sites

\section{Figure 3}


Evolution trend of growth in total height (length of stem) of $R$. racemosa in relationships to salinity and sites

\section{Figure 4}

Evolution trend of number of leaves of $R$. racemosa in relationships to salinity

\section{Figure 5}

Relationships between above-ground and below-ground biomass across two sites

\section{Figure 6}

Biomass allocation and water uptake patterns in R. racemosa at sapling stage at (a) Azizakouè and (b) Lanhou

\section{Figure 7}

Biomass repartition among plant parts

\section{Figure 8}

Caterpillar (Phytophagus sp): predator of leaves of $R$. racemosa 